\title{
Religious Peace building, the Problems, and Potentials Now and in the Foreseeable Federal Republic of Nepal ${ }^{1}$
}

\begin{abstract}
Mukti Suvedi
Abstract

Introduction: There is debate whether most Nepali people still want Nepal to be a Hindu state. A significant number of opinions wish to see the country as secular, where people are respected with dignity without any discrimination where people can profess, practice, and protect their religions, whichever religion it may be.

Methods: This paper is based on public opinion surveys through interviews and discussions with100 individuals, including key informant interviews with 25 religious leaders from different religions conducted between September 20019 and February 2020 and secondary data from various literature reviews.

Results: The paper's finding reveals that the public's preference toward the Hindu state is not accepted in all sub-national levels; a secular state preference is evident in some of the sub-national levels, which cannot be undervalued. The mindsets of most of the elder populations interviewed still want Nepal to be the only Hindu state in the world, whereas the active young-age (youth) population is more inclusive and is happy with the secular nation.

Conclusion: Understanding and implementing inclusive secular policies and practicing the preexistence principles of religious freedom by the political parties and incorporating the same in all government, semi-government and private sectors will ensure a secular and peaceful Nepal. Government authorities and other bureaucrats becoming more sensitive towards religious issues will create space for promoting peace.
\end{abstract}

Key Words: Religion, conflict, peace building, Nepal

\section{Introduction}

\footnotetext{
${ }^{1}$ Cite this article as: Suvedi, M. (2021). Contemporary Research: An Interdisciplinary Academic Journal, vol. 5 (1) DOI: https://doi.org/10.3126/craiaj.v5i1.40483

Mukti Suvedi, peace practitioner, educator, facilitator, works in South Asia

Email: muktisuvedi@gmail.com

Article history: Received on June 5; Accepted on August 24; Published on October 21

Peer reviewed under the authority of CRAIAJ, academic journal of Ghodaghodi Multiple Campus, Kailali, Nepal, with ISSN 2717-4611 (Print) and ISSN 2717-462X (Online).

(C) 2021 CRAIAJ
}

Full text of this article can be downloaded from www.craiaj.com and www.nepjol.info 
Religion is a concern in many societies and communities in Nepal. It is because many people have experienced some forms of discrimination, either caste-based or beliefbased. Many times, religious tension, conflict domination, and engagement in case-based or belief-based discourses are visible in Nepal's news portal. Despite the secular country, frequencies of news on caste and belief-based conflict and violence needed more attention. Until May 18, 2006, Nepal was constitutionally a Hindu country; however, the Interim Constitution of 2007 defined Nepal as a "secular, inclusive and fully democratic federal state" and a "multiethnic, multilingual, multi-religious and multicultural" country.

It thereby replaced the Constitution of 1990, which had enshrined the 'Hindu' identity of the country and its monarchy. Nepal is a country with religious, social, and cultural diversity. There are ten major types of religious categories reported in the census of 2011. Hinduism is followed by 81.3 percent $(21,551,492)$ of the population while Buddhism (9.0\%; 2,396,099), Islam (4.4\%; 1,162,370), Kirat (3.1\%; 807,169), Christianity (1.4\%; 375,699), Prakriti (0.5\%; 121,982), Bon (13,006), Jainism $(3,214)$, Bahai $(1,283)$ and Sikhism $(609)^{2}$.The country with an area of 54,363 square miles and a population of 30 million constitute 80 percent of the population as Hindus, Buddhists 9 percent, Muslims (the majority are Sunni or Sufi) 4 percent and Christians and others 1 to 3 percent. According to the National Churches Fellowship of Nepal, almost 400 Christian churches operated in the Kathmandu Valley alone. According to a Jamia Masjid (mosque) official, at least 3,600 madrassas are associated with a mosque. ${ }^{3}$

Before 2006, there was suppressive religious tension visible in the societal structure. Various forms of discrimination against non-Hindu (besides Buddhists) were evident in rural and even urban parts of the country. Many field visits to a remote part of the country confirmed that caste-based discrimination was the primary reason for converting the so-called lower caste or scheduled caste into other religions. Even though the democratic Constitution of 1990 maintained a religious character as a Hindu state, minority religious groups started breathing freedom to profess and live according to their faith and culture under it as it awarded political rights and civil liberties. Still, the state's formal declaration in 2006 as secular by the Constitution imposed particular restrictions on religious minorities, including proselytizing and converting. Muslims, Christians, and

\footnotetext{
${ }^{2}$ National Population and Housing Census (2011), Annual Report, Government of Nepal, 2011.

${ }^{3}$ US Embassy, Nepal Religion and Freedom Report, Kathmandu, 2011.
}

Full text of this article can be downloaded from www.craiaj.com and www.nepjol.info 
various minority groups felt that their culture, religion, and language were knowingly curbed by the majority monolithic Hindu-elite-backed state that spoke the Nepali language and wore the hill attire. Some Hindus who were interviewed accused that these minorities have changed their religions for materialistic and financial benefits.

On the other hand, minorities wanted Nepal to become a secular state to make the country more inclusive. Following the 2006 People's Movement, the interim government was formed, which overthrew the King's direct rule and declared Nepal a secular state. Non-Hindu citizens feel that the state has also given them respect after Nepal was declared a secular state. However, they blame that the declaration is not really working in practice or implementation remains discriminatory.

\section{Methodology}

The paper was analyzed based on the review and analysis of secondary data and documents available. This paper is based on public opinion through a discussion with 100 individuals conducted between September 20019 and February 2020. The secondary source of information analysis and interpretation of data from the Nepal governments were studied and analyzed. The research team has conducted telephone and in-person interviews with religious leaders from Hindu, Christian, and Muslim religions. Key informant interview (KII) was the primary source for collecting preliminary information. The team interviewed 25 religious leaders from different faiths, and similarly, 10 individuals were working in organizations who had contributed in religious peace building and 55 others who were general public, students, professors, and NGO workers. There was one focus group discussion (FGD) with 10 individuals who participate in the FGD in Kathmandu. The religious leader was selected based on their availability of time for the interview, and similarly, identified organization members were contacted for the interview. Eleven interviews were conducted on the telephone, and the rest were in-person meetings. The interview was conducted between September 20019 and February 2020.

\section{Table 1}

Interviewed population by age group, according to sex

\begin{tabular}{|c|c|c|c|}
\hline & Female & Male & Total \\
\hline 25-29 years & 6 & 4 & 10 \\
\hline
\end{tabular}

Full text of this article can be downloaded from www.craiaj.com and www.nepjol.info 
Contemporary Research: An Interdisciplinary Academic Journal, 2021, vol. 5 (1): 63-78

\begin{tabular}{|c|c|c|c|}
\hline 30-34 years & 8 & 4 & 12 \\
\hline 35-39 years & 6 & 3 & 9 \\
\hline 40-44 years & 5 & 9 & 14 \\
\hline 45-49 years & 3 & 4 & 7 \\
\hline $50-54$ years & 3 & 6 & 9 \\
\hline 55-59 years & 6 & 6 & 12 \\
\hline 60-64 years & 7 & 4 & 11 \\
\hline $65-69$ years & 3 & 2 & 5 \\
\hline 70-74 years & 1 & 0 & 1 \\
\hline 75-79 years & 1 & 0 & 1 \\
\hline 80-84 years & 3 & 4 & 7 \\
\hline 85 years and above & 1 & 1 & 2 \\
\hline Total & 53 & 47 & 100 \\
\hline Religion & Female & Male & Total \\
\hline Hindu & 13 & 9 & 22 \\
\hline Buddhist & 11 & 13 & 24 \\
\hline Muslim & 8 & 9 & 17 \\
\hline Christian & 17 & 15 & 32 \\
\hline atheism (Libral) & 4 & 1 & 5 \\
\hline Total & 53 & 47 & 100 \\
\hline
\end{tabular}

Discussions: Societal Structure and Discourses

\section{Figure 1}

Full text of this article can be downloaded from www.craiaj.com and www.nepjol.info 


\section{Traditional Nepalese Caste System}

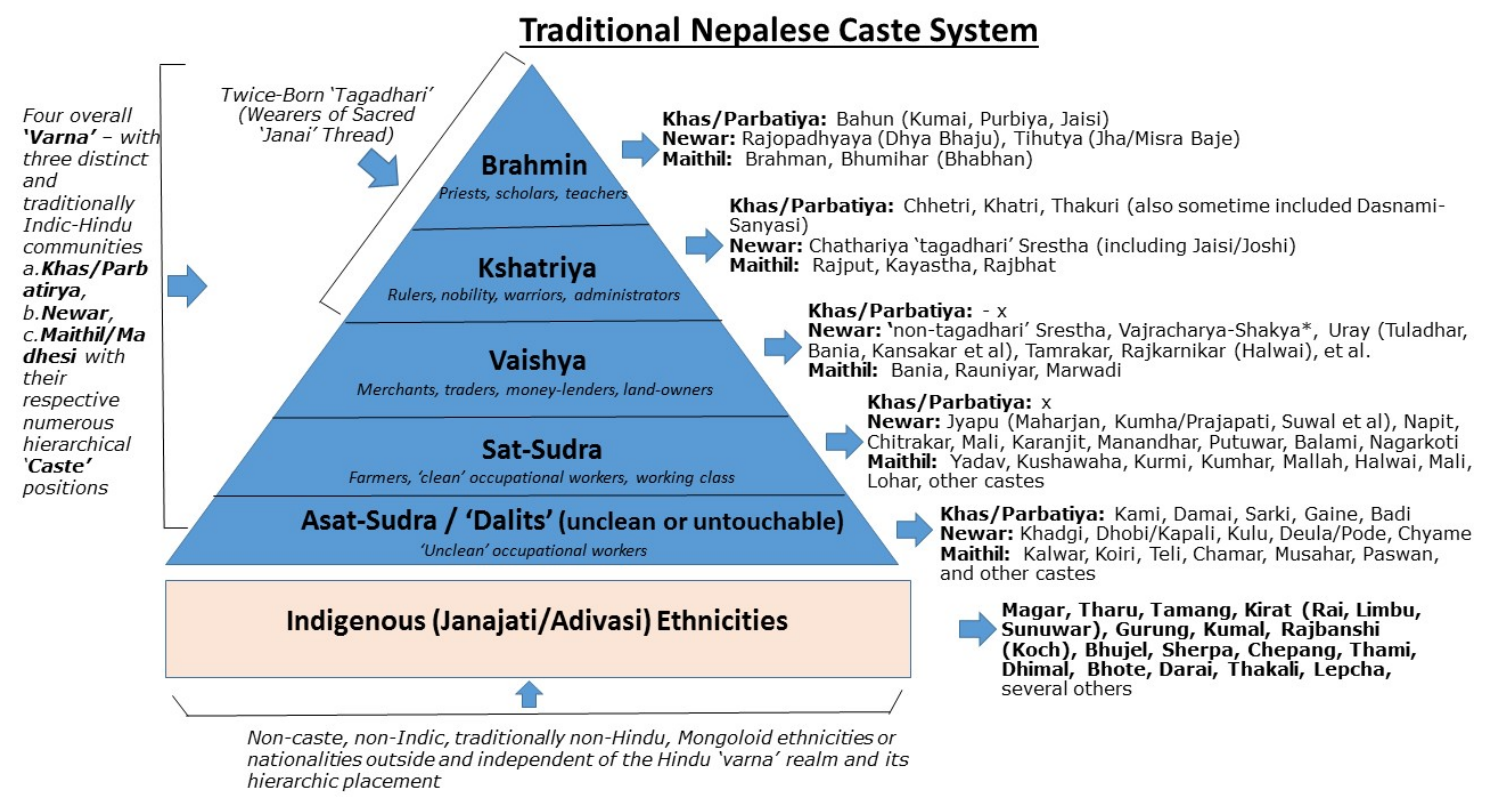

King Prithivi Narayan Shah, who founded modern Nepal in the eighteenth century, divided the country into four main castes and 36 Varna or sub-castes (see Figure 1). These castes were divided on the work individual perform or professions' basic, which remains a significant dominant aspect in promoting discrimination despite good intention with a metaphor of a garden of various flowers. The caste-based discrimination enrooted in society even promoted untouchables classes ${ }^{4}$. The box figure shows how the Hindu Castesystem was practiced and is still practiced in rural settings.

From the above structure, people at the top got the privileges and bottom of the pyramid were considered untouchables; experienced torture, and discriminated against in the name of many evils in Nepali society. Women at this level were treated as witches and fed with human excrete ${ }^{5}$.

All those four main castes and 36 sub-caste have their pyramid of the caste system. Each caste has a hierarchy in its caste system and has been practicing many harmful practices. For example, the picture above shows the basics of overall caste-based hierarchy,

\footnotetext{
${ }^{4}$ People were treated as a lowest in the caste system and were not touched by the higher caste. They were treated unholy and if somebody touches they would have to take holy shower.

${ }^{5}$ UN Nepal, 2020, "Literature Review on Harmful Practices in Nepal”.
}

Full text of this article can be downloaded from www.craiaj.com and www.nepjol.info 
and others like Newar, one caste with the hierarchy of sub-caste, and Pode and Chayme, who were considered toilet cleaner sweepers, were categorized the lowest in the triangle. The harmful societal and cultural practices that Nepali societies are practicing are namely: caste-based discrimination, menstrual restrictions including Chhaupadi, child marriage, dowry and dowry-related violence, witchcraft accusations, and persecution.

The very recent incidents that happened in March 2020, killing six youths in Soti village of Chaurjahari municipality in Rukum (West), resulted from caste-based discrimination prevalent in society, an investigation by a parliamentary committee has concluded. Incidents with such gravity still prevail in Nepali society. Nepal is a signatory of various UN treaties related to discrimination, such as the International Convention on the Elimination of All Forms of Racial Discrimination on 30/1/1971, International Covenant on Economic, Social and Cultural Rights on 14/5/1991, International Covenant on Civil and Political Rights on 14/05/1991 ${ }^{6}$.

On May 24, 2011, Nepal's legislature passed the bill on Caste-Based Discrimination ${ }^{7}$ and Untouchability. This bill was designed to end discriminatory practices visible in the societies for the lowest castes, known as "Dalits". The legislation prohibits caste-based discrimination and individuals' treatment as "untouchable" in public and private spheres; this bill establishes increased punishment for officials guilty of discrimination. Despite all the government-level effort, serious implementation at the community level is yet to be assured. Similarly, a Dalit woman had been beaten for touching the water pipes in Tokha of Kathmandu. Kamala Nepali, a long-time resident of the area, was in dispute with Shanta $\mathrm{KC}$ of the same place over filling water at a tap near Shanta's house. ${ }^{8}$ Similar cases where a landlady expelled a Dalit student preparing for MBBS based on his caste. The landlady, ousted the student from Lamjung district, although she had already agreed to rent a room in her house in Syuchatar area of Katmandu ${ }^{9}$.

\section{Understanding Communal and Religious Tensions in Nepal}

There is mostly discussion if Nepal's religious ideologies cause the violence or if

\footnotetext{
${ }^{6}$ Government of Nepal, Ministry of Law, Justice and Parliament Affairs, 2018. ${ }^{7}$ http://www.lawcommission.gov.np/en/archives/15846, accessed on 20 September 2020.

${ }^{8}$ Huff post,2016-02-17 , by Kishor Panthi, https://www.huffpost.com/entry/untouchable-modernnepals b 10309260, accessed on 10 October 2020.

${ }^{9}$ Ibid
}

Full text of this article can be downloaded from www.craiaj.com and www.nepjol.info 
the religion is considered a tool in the hands of those seeking to gain through the violence and if the religious ideologies are used for political gain. Whatever the case be, communal and religious violence has impacted many people and families lives. Many times followers of one religion are dominated by other religions and have been engaged in discourses and emerged as communal violence. The coexistence among the different religious and communal groups has changed over the years in political transformation.

Religion-wise Hindu and Buddhist are the privileged religion in Nepal, whereas it is evident from the available historical accounts that Muslims and Christians were treated as outcasts from 1768 until the middle of the 20th century (both socially and politically) ${ }^{10}$. This period witnessed repression against non-Hindus and lower castes - the history of how Christians came into Nepal. Nepal state head welcomed Christian missionaries in 1950 and offered lands for investing in modern education. St. Xavier Schools in the Godavari area of Katmandu was created in 1951, among others. Despite the Christian Father and Sisters' invitation to practice their religious faith in a confined place, the conversion was illegal in Nepal. Any act against Hinduism was penalized by arresting several arrests for acts of proselytism as the laws of the land banned proselytism.

The democratic Constitution of 1990 maintained a religious character of Nepal as a Hindu state, but minority religious groups started breathing freedom to profess and live according to their faith and culture as the Constitution awarded political rights and civil liberties. Still, the Constitution imposed restrictions on religious minorities, including proselytizing and converting. Muslims, Christians, and various minority groups felt that their culture, religion, and language were being knowingly curbed by the majority monolithic Hindu-elite ${ }^{11}$. Despite all the suppressive discrimination, the rituals like funerals were taking place in Teku Ghat, where Buddhists, Christians, and Hindu performed their rituals together. Secular state and freedom of religious practice had been a demand for many years and was realized when an interim government that was formed after 2006 overthrew the King's direct rule and declared Nepal a secular state. Non-Hindu citizens feel that the state has also given them respect since Nepal was declared a secular

\footnotetext{
${ }^{10}$ https://cbs.gov.np/, accessed on 10 October 2020

${ }^{11}$ Pandey, N. N., \& Delinic, T. (2013). NEPAL'S NATIONAL INTERESTS - II Secularism, Free and Responsible Media and Foreign Employment (1st ed.). Centre for South Asian Studies (CSAS), Konrad Adenauer Stiftung (KAS).
}

Full text of this article can be downloaded from www.craiaj.com and www.nepjol.info 
state.

However, some Hindu leaders and political activists protested against the decision on secular state and protested against the declaration. There were arguments among the think-tank and politician later had recommended at least for understanding people's sentiments. Demonstrations and rallies were reported in many places, including Kathmandu, Chitwan, and Birgunj. The rallies waved tridents and saffron flags and shouted slogans. They claimed that the interim government's decision betrayed the expectation of 80 percent of the Hindu people. Even some in the Muslim community came to the streets to supported the protest. Babu Khan Pathan, a Muslim chairperson of Rastrabadi Muslim Manch in Nepalgunj, highlighted that "turning the country secular is nothing but a design to break the longstanding unity among Muslims and Hindus. So there is no alternative to reinstating the country's old Hindu State identity in order to allow fellow citizens to live with religious tolerance." 12

After declaring a secular state, Nepal experienced different forms of violent attacks on religious institutions. The Catholic Church in Kathmandu was bombed, killing two innocents and 13 injured. Similarly, a Muslim leader was shot to death while leaving a mosque in Kathmandu. Nepal has witnessed several murders and attacks against religious minorities, usually at Hindu extremist groups. In 2008, shooters belonging to an extremist fringe shot to death a Christian priest ${ }^{13}$. On April 26, 2008, a Hindu extremist group detonated a bomb inside the mosque, killing two people.

Similarly, the Kapilvastu carnage, in the form of Madheshi and Pahadi ${ }^{14}$ ethnic violence erupted after the murder of the Muslim landlord and a local leader Mr. Mohid Khan in September 2007, had left 14 people dead and several thousand displaced. The carnage almost took the form of religious tension between Muslims and Hindu. A Nepali Congress politician Mr. Loknath Sharma, was burnt down for being a Pahadi community member in a Muslim village ${ }^{15}$. Because of such incidents, Pahade origin people living in the Terai belt with densely populated Muslim and Madheshi communities left the village because of insecurity and fear. Because of this fear, Nepal's Muslim community leaders

\footnotetext{
${ }^{12}$ https://thehimalayantimes.com/nepal/muslims-demand-hindu-state/, accessed on 10 October 2020.

${ }^{13}$ https://www.vomcanada.com/np-2008-07-08.htm, accessed on 10 October 2020

${ }^{14}$ The United Nations High Commissioner for Refugees, "Religion Freedom in Nepal" Kathmandu, 2010.

${ }^{15}$ Caritas Nepal, “Religious Tension in Kapilbastu, Report”, Caritas Nepal, 2009.
}

Full text of this article can be downloaded from www.craiaj.com and www.nepjol.info 
have repeatedly said that they do not want to be a part of a Madhesi province; and there was retaliation against the party cadre in Banke that turned violent by evening. A curfew was announced, but the violence continued unabated with looting and vandalism ${ }^{16}$.

Some political and religious parties are demanding to reinstate Nepal as a Hindu State ${ }^{1718}$. These political and religious groups had organized several protests against secularism. Those groups' leaders have been stating that the people's sentiments are not addressed and claim that reinstating Nepal as a Hindu state addresses Hinduism's aspiration in the country.

In secular Nepal, religion has been the debate and most sensible issue raised by people. Nepal is declared a secular state; the Churches in Nepal are not legally recognized; many churches are registered as Non-Governmental organizations (NGOs). Many Hindu sentiments have been alarmed by Christianity's growth, and some have formed extremist groups and attacked churches. Converts have occasionally had a deal with social ostracism and (rarely) violent persecution. Muslims in Lumbini have started building Mosques around Buddhist Heritage sites. For instance, when I visited Lumbini in 2004, there was hardly one Mosques, and now you can see over six Mosques. In the year 2000, we could barely see any women in burkas; in areas like Kapilbastu, Lumbini, Rupendehi districts, now you see women and girls with burkas all around the markets.

Despite the strict norms and policies against conversion, there is growth in other religions. However, the argument lies if people can choose the religions of their choice freely or not. Shradda Thapa's raises one fundamental question in her article published on Republica:"If the fear is of a diminishing Hindu population, shouldn't the objective be to share the merits of Hinduism rather than attack to Christianity." ${ }^{19}$ Yes, this has

\footnotetext{
${ }^{16}$ Nepali Times, 20 November 2014, by Basanta Upadhyay https://archive.nepalitimes.com/article/nation/When-Banke-burned, accessed on 10 October 2020.

${ }^{17}$ Press Trust of India, “Nepal party demands reinstatement of Hindu state”, New Delhi, 2019.

${ }^{18}$ Nirmala Carvalho, "Nepalese party wants to refound the Hindu state. Concern for Christians”, Asia

News, 2019

${ }^{19}$ Republica, Newspaper, 7 July 2011, Kathmandu

Full text of this article can be downloaded from www.craiaj.com and www.nepjol.info
} 
connectedness with the societal structure where Dalits ${ }^{20}$, Janajatis, and indigenous community people were outcaste from the mainstream Hindu religions. In a Hindu community, these people were not allowed to touch the drinking water, were restricted from fetching water from the same well or source, and were restricted from entering the Hindu temples. Almost 100 Christian pastors were interviewed while writing this article, the main reason behind the conversion was asked, and almost $80 \%$ of the respondents reported that they felt the discrimination in society against Dalit and indigenous.

Similarly, a religious campaign and a special prayer at Pashupatinath Temple ${ }^{21}$ demanded that Nepal be reinstated as a Hindu country. Spontaneous debate either reinstating Nepal as a Hindu country and a secular state is going on. Similarly, a group from the political parties feels that it was undemocratic to declare Nepal a secular state without a referendum, therefore demand a referendum on the declaration. They have further accused the Christians of converting Hindus by pouring in millions of rupees in the name of 'change is possible.' Adding on to this, the ongoing issue of Christians demanding burial grounds and undertaking a chain fast, seeking the government to grant them burial land. The Muslims who have not raised any issues about the burial grounds have supported them in this demand. Furthermore, the Christian leaders share that conversion clauses demand that the Constitution remove the clause preventing forced conversion. Given the increased religious activities in Nepal, it will be interesting to see what happens next.

The latest development and threats to religious institutions have developed a culture of threats and fear among the believers of different religions. Freedom of practicing different religions is not adequately respected in the present context of Nepal. Despite the country being declared a secular state, the equal representation of the religions in the government and government intuitions is not adequate. The exclusion culture is also prevailing in the community, causing discrimination in the community. Christians are the subjects and are discriminated against while in government offices and socially outcaste when any community members are converted.

\section{Muslims and their Relationship with Hindu}

\footnotetext{
${ }^{20}$ Dalits belong to a caste. See http://www.ccd.org.np/publications/dalit\%20of\%20nepal\%20and\%20a\%20new\%20constituition.pdf ${ }^{21}$ A famous Hindu Temple in Nepal. (It is located in Kathmandu, the capital of Nepal)
}

Full text of this article can be downloaded from www.craiaj.com and www.nepjol.info 
Muslims in Nepal are found to have arrived in Nepal only in the late medieval age. Muslims arrived from different parts of the world, i.e., from India and the Arab peninsula. The first Muslims from Kashmir were invited by the then Nepali rulers in the $15^{\text {th }}$ century to benefit from their trade and technology skills preceeding followed by Afghans, Persians, and Arabian. The Iraqi market in Indrachowk is often cited as proof of Arab Muslims' existence in Nepal in history ${ }^{22}$. The divided dynasties (Chaubise Rajya) of Nepal also employed Afghan and Indian Muslims to train Nepali soldiers to use firearms and ammunition $^{23}$.

The first batch of Muslims came with a Kashmiri saint and built the first mosque, Kashmiri Taquia, in $1524^{24}$.Many Muslim populations migrated to Nepal during the Indian Mutiny, also called Sepoy Mutiny or First War of Independence in India, in 1857-59.Many Muslims who flee the War of Independence in India came and settled in Terai, mostly in western Terai. One among many who took refuge in Nepal was Begum Hazrat Mahal, also known as Begum of Awadh, a very popular queen of Nawab Wajid Ali Shah, the last King of Awadh India. Mahal died in 1879, and her funeral tomb is still located in Jama Masjid in Ghantaghar, Kathmandu, Nepal ${ }^{25}$. Since the Muslim population increased and has been living and contributing to the country's economic developmentthe Muslim population ranks $3^{\text {rd }}$ after Hindu and Buddhist.

In Nepal, Muslims lived in a silent minority for many years and were overlooked by Nepal's Government for all these years. In 2008 Muslim holiday was recognized by the Government of Nepal and declared a national holiday. This was a great honor for the acceptance of the dignity of the Muslim population. Similarly, the government establishes the Muslim Commission in 2017 to work to better the country's Muslim people. The Government of Nepal appointed the Muslim commissioner in the Muslim commission to enhance, develop strategy, and work to better the Muslim population.

The Muslims in Nepal were considered business people because of their business involvement; they were easily mingled in societies. However, in recent times, the more

\footnotetext{
${ }^{22}$ Narad Bharadwaj, 'Islamic Community in Nepal’, The Rising Nepal, accessed on 23, Sept 2020

${ }^{23}$ Siddika, Shamima (1993). "Muslims of Nepal”

${ }^{24}$ Ibid

${ }^{25}$ Narayan, Badri (February 2004). "Inventing caste history: Dalit mobilization and nationalist past". Contributions to Indian Sociology.
}

Full text of this article can be downloaded from www.craiaj.com and www.nepjol.info 
radical practice of ideology has been a concern. Many migrant Muslims in the Middle East and Gulf came back with more traditional and radical cultural practices, evident in the country's Terai side. Many more women and girls with burkas were seen than that of 5-10 years earlier. Likewise in COVID-19 case Muslims were blamed and accused of spreading the COVID-19 virus in the community during the first phase.

\section{Christian and their Relationship with Hindu}

According to the 2011 census, the Christian religion is the fifth most practiced religion in Nepal, with 375,699 adherents, or $1.4 \% .{ }^{26}$ However, there is always a debate on the number of Christians, as many Christian groups claim the total is over one million Christian adherents. It is interesting to see how and when the Christian religion entered Nepal. For the first time, the Christian word used in any book was on an important book on China where some reference on Necbal (Nepal) was published in the year $1667^{2728}$.

When Pratap Malla was ruling Kathmandu valley, Catholic Jesuit Priest Johanne Grueber and Albert d'Orville visited Nepal and were asked by the King to stay and do the missionary work. They stayed for a month, and because of the extreme climate, there was no record of any missionaries and Christian faith being established until 1715, when the first Christian mission to Nepal was established by Catholics Capuchin friars, ${ }^{29}$ who worked in Kathmandu Valley. There were few conversions of locals to Christianity ${ }^{30}$. After the unification of Nepal's Kingdom in 1769 by King Prithivi Narayan Shah, the Capuchins and the Christians were expelled. The Christian groups were officially banned from the country for over two centuries. ${ }^{31}$

\footnotetext{
${ }^{26}$ Nepal Central Bureau of Statistics (2011) 'National Population and Housing Census 2011.’ p. 4. Retrieved 27 September 2020.

${ }^{27}$ Kircher, A. (1667). Athanasii Kircheri ... China monumentis: Qua sacris qua profanis, NEC non variis naturae [et] artis spectaculis, aliarumque rerum memorabilium argumentis illustrata.

${ }^{28}$ Shrestha, D. B., Singh, C. E., \& Singh, C. B. (1972). The history of ancient and medieval Nepal in a nutshell: With some comparative traces of foreign history. HMG Press Kathmandu, Nepal.

${ }^{29}$ Barclay, J. (2009) 'The Church in Nepal: Analysis of Its Gestation and Growth.' International Bulletin of Missionary Research 33 (4):189-194. p. 189

${ }^{30}$ Alsop, Ian (1996) 'Christians at the Malla Court: the Capuchin 'piccolo libro'.' In Change and continuity: studies in the Nepalese culture of the Kathmandu Valley, edited by Siegfried Lienhard. Alessandria:

Edizioni dell'Orso. p. 123.

${ }^{31}$ Barclay, J. 2009, p. 189.
}

Full text of this article can be downloaded from www.craiaj.com and www.nepjol.info 
After the overthrow of the Rana regime in 1951, King Tribhuvan opened the outside world's borders and appealed to support Nepal's development. ${ }^{32}$ With this invitation and the school's land in the Godavari, Fr. Marshall Moran established St. Xavier's School in 1951. ${ }^{33}$ Jesuit missionaries' schools made notable contributions to education in Nepal. Whatever the context, conversion to Christianity was forbidden by law. Many Hindus who believe that Christian schools are providing better quality education have a soft corner space for Christian institutions. Many Government officials, elite group kids, and political party leader's children received education from Catholic schools. Catholic Christians usually take part in Hindu festivals such as Bhai Tika and Dashain. Nepali Catholics have played leading roles in promoting interreligious dialogue in recent decades, and Kathmandu's Assumption Cathedral incorporates Newari and Tibetan styles of architecture and mural painting.

Similarly, an organization like United Mission to Nepal (1954), International Nepal Fellowship (1951), which was called Nepal Evangelistic Band (NEB) were established for the social work and health care in Nepal. Many hospitals and social service programs were implemented to support the Nepali people and the government. Despite being the Christians, the organization established has enormously served the non-Christians.

\section{Religious Peace Building in Nepal}

The political parties and of Nepal believed that the state's declaration as secular would solve the problems. However, the declaration of the state without any homework and inclusive, participatory discussion on what aspects secularism should consider with all the other religions could not present the essence of secularism. In this context, state and religious leaders have an important role in preventing and reducing religious zest conflict and making people understand the essence of being secular and promoting positive change. Many international organizations are running similar programs to engage with religious leaders; various discussion events and interreligious programs designed to promote tolerance, acceptance, and coexistence in societies ${ }^{34}$.

\footnotetext{
32 Barclay, J. 2009, p. 190.

33 Barclay 2009, p. 191.

${ }^{34}$ Most of the organization who are running the similar nature of programs are Christian and are funded by Christian organizations.
}

Full text of this article can be downloaded from www.craiaj.com and www.nepjol.info 
Change at the government level is visible; after the declaration of a secular state, the Government of Nepal also tried showing concern to other religions and eventually declared Christmas and Eid as national holidays. The continued discussion and consultation are needed with Nepal's Government to make the policy level understand and consider the secular Nepal concept's minimum benchmark. Nepali political leaders need to get broader and get rid of the traditional structural Hindu practices and discriminating against other religions.

NGOs in Nepal are very active in realizing the emergence of possible religious conflict. Caritas Nepal, United Mission to Nepal, Interreligious Dialogue, Interfaith Groups, Sanjal, etc. are some organizations working for religious peace building in Nepal. These organizations' religious peace building programs aim to reach more individuals focuses mostly on religious leaders, youths, community members, NGO leaders, and children in schools. Religious dialogue and inter-religious programs are undertaken to empower people. Roles, rights, and responsibilities of religious, spiritual, and civil society ${ }^{35}$ organizations in implementing the commitment to freedom of religion are yet to be discussed at the higher and policy levels. Peace education, which includes inclusive interfaith and interreligious harmony, is what Nepal's education system is missing from childhood.

\section{Conclusion}

The Constitution of the country in part 3, under fundamental rights and duties, article 26 (1) states, "Each person shall be free to profess, practice, and preserve his/her religion according to his/her faith."To profess means "to affirm, or declare one's faith in or commitment to one religion. However, how can one separate if one has, in fact, "professed" a religion? A proper analysis of the entire circumstances is necessary. If a person who understands Christianity and wants to become a Christian needs to be baptized, it follows a conversion process. But one major problem Christians have been accused of is religious conversion. The Constitution says that nobody shall be entitled "to convert another person from one religion to another."Someone born into the religion is held to be a member of that religion unless it is proved he adopted some other religion. How can a person adopt, profess, and practice?

The Government of Nepal and other concerned authorities need to understand that

\footnotetext{
${ }^{35}$ Babie, P., \& Rochow, N. (2012). Freedom of religion under bills of rights. University of Adelaide Press.
} 
each individual should be treated equally despite their religion. Many Christians and Muslims have shared that the Government authorities and other bureaucrats are less sensitive and have not best handled religious issues. The paradigm of discrimination on caste-based should not be shifted upon other minority religions because Dalit and indigenous communities are converted to other religions.

The person born in a Hindu family remains Hindu; it might be argued that the freedom to renounce one's religion or profess not to have a religion is a consequence of the freedom to profess a religion. This means a Dalit born in a Hindu family can renounce his religion and profess Christianity or Buddhism. However, there is a need to find the legal ground which could be argued and presented. The government and legal system need to clarify this pulverized to make it clear understanding. The Constitution of Nepal is also silent on what constitutes practicing and protecting religion. The federal and local courts have to define the word practice by indicating what acts are not considered religious practices. If it is up to the individual religious institution to decide what constitutes religious practices that do not offend public interest, it should also prevent potential future conflict.

\section{References}

Alsop, I. (1996). Christians at the Malla court: the Capuchin 'piccolo libro'. In Change and continuity: Studies in the Nepalese culture of the Kathmandu Valley (p. 123). Edizioni dell’Orso.

Barclay, J. (2009). The Church in Nepal: Analysis of its gestation and growth. International bulletin of missionary research, 33(4), 189-194, doi:10.1177/239693930903300406

Caritas Nepal. (2009). Religious tension in Kapilbastu, Report. Author.

Carvalho, N. (2019, April 8). Nepalese party wants to refound the Hindu state. Concern for Christians. Asia news.

Kircher, A. (1667). Athanasii Kircheri ... China monumentis: Qua sacris qua profanis, NEC non variis naturae [et] artis spectaculis, aliarumque rerum memorabilium argumentis illustrata.

Naffine, N. (2012). How religion constrains law and the idea of choice. In freedom of religion under bills of rights (pp. 12-28). Adelaide, Australia: University of Adelaide Press. 
Narayan, B. (2004). Inventing caste history: Dalit mobilisation and nationalist past. Contributions to Indian Sociology, 38(1-2), 193-220, doi:10.1177/006996670403800108

Nepal Central Bureau of Statistics. (2014). Statistical pocket book Nepal 2014.

Panthi, K. (2016, February 17). Untouchable: Modern Nepal's shame \& an untouchable woman's adventurous journey. Huff Post. Retrieved from , https://www.huffpost.com/entry/untouchable-modern-nepals_b_10309260

Shrestha, D. B., Singh, C. E., \& Singh, C. B. (1972). The history of ancient and medieval Nepal in a nutshell: With some comparative traces of foreign history.

Siddika, S. (1993). Muslims of Nepal.

United States. Congress House Committee on international relations. (2011). Annual report on international religious freedom: Report submitted to the committee on international relations, U.S. House of Representatives and the committee on foreign relations, U.S. Senate.

United States. Department of State. (2000). Annual report, international religious freedom: Report submitted to the committee on international relations, U.S. House of Representatives and the committee on foreign relations, United States Senate by the Department of State, in accordance with section 102 of the international religious Freedom Act of 1998.

Vibhāga, N. K. (2014). National population and housing census, 2011: Tables from form-II.

VOMC. (2008, July 8). Priest killed by Hindu militants in Nepal. Retrieved from https://www.vomcanada.com/np-2008-07-08.htm 